\title{
Use of FAMACHA to Detect Anaemia and Control of Gastrointestinal Parasite in Goats of A and N Islands, India
}

\author{
Jai Sunder, D. Bhattacharya, T. Sujatha, A.K. De, G. Chakraborty, S.C. Mayuri,
} P. Perumal, S. Bhowmick, R.R. Alyethodi, E.B. Chakurkar

10.18805/IJAR.B-4754

\begin{abstract}
Background: FAffaMAlanCHArt (FAMACHA) is a technique for treating the animals infested with gastrointestinal parasites by using clinical anaemia as the determinant. The test is based on the assessment of colour variation of the conjunctival mucous membrane. Methods: In the present study FAMACHA has been standardized and used to correlate the anaemic status of goats with faecal egg count (gastro intestinal parasites) and blood profile. On the basis of FAMACHA score and faecal egg count, the goats were treated with benzimidazole compound and macrocyclic lactone.

Result: The result indicated significant $(P<0.05)$ reduction in the faecal egg count of Haemonchus spp from $1200 \pm 155.76$ to $525 \pm 75$, Strongyloides spp from $469.57 \pm 77.37$ to $78.26 \pm 33.83$ and Eimeria spp from $900 \pm 240.05$ to $195.65 \pm 55.34$ respectively. FAMACHA score of anaemic goats improved from $4.08 \pm 0.11$ to $3.2 \pm 0.13$. Mean haemoglobin ( $\mathrm{g} / \mathrm{dl}$ ), packed cell volume (PCV), red blood cell (RBC) and white blood cell (WBC) improved from 8.33 to 8.99, 22.66 to 24.86, 13.73 to 14.76 and 18029 to 19894 , respectively which indicated clinical improvement. Highly significant $(P<0.01)$ correlation was observed between the FAMACHA score and the haemoglobin level. It could be concluded that FAMACHA is a very handy tool to detect anaemic status of the animals and correlate with gastrointestinal parasitic load.
\end{abstract}

Key words: Blood profile, FAMACHA, Gastrointestinal parasites, Goat.

\section{INTRODUCTION}

The Andaman and Nicobar Islands are a group of more than 572 islands, islets, rocks etc. lies between $6^{\circ}$ and $14 \mathrm{~N}^{\circ}$ latitude and $92^{\circ}$ and $94^{\circ} \mathrm{E}$ longitude. The island receives more than $3100 \mathrm{~mm}$ rain annually while the temperature varies between $18-35^{\circ} \mathrm{C}$. The climatic condition of Andaman and Nicobar group of islands is hot and humid which favours the growth and proliferation of endoparasitic infestation in large and small ruminants (Sunder et al., 2019). Climate plays a very important role in proliferation and growth of gastrointestinal parasites (GIN). Report suggests that the gastrointestinal infestation usually reported from the tropical hot and humid countries (Gadahi et al., 2009; Domke et al., 2013). The climatic condition of the islands is also very conducive for proliferation of these parasites. Studies carried out in the islands showed very high $(61.31 \%)$ prevalence of parasitic infection (CIARI, Annual Report 2018-19). Amongst the various parasitic cases the incidence of ascariasis, fascioliasis, strongyloides, amphistomiasis and haemonchosis are reported to be very common with number of cases per thousand animals ranged from 100 to 600 (Sunder et al., 2019). The infection of gastrointestinal parasites usually associated with low productivity in meat, milk, infertility problems, morbidity and in some cases mortality (Vanessa et al., 2014; Mohammed et al., 2016).

Worldwide, the most common gastrointestinal parasites reported are Haemonchus contorus and Trichostrongylus spp. in the small ruminants (Sani and Chandrawathani, 1996; Tan et al., 2014). Various reports are available which suggest the common prevalence of H.contortus, Ostertagia $\mathrm{sp}$ and
Division of Animal Science, ICAR-Central Island Agricultural Research Institute, Port Blair-744 105, Andaman and Nicobar Islands, India.

Corresponding Author: Jai Sunder, Division of Animal Science, ICAR-Central Island Agricultural Research Institute, Port Blair-744 105, Andaman and Nicobar Islands, India. Email: jai.sunder@icar.gov.in How to cite this article: Sunder, J., Bhattacharya, D., Sujatha, T. De, A.K., Chakraborty, G., Mayuri, S.C., Perumal, P., Bhowmick, S., Alyethodi, R.R. and Chakurkar, E.B. (2022). Use of FAMACHA to Detect Anaemia and Control of Gastrointestinal Parasite in Goats of A and N Islands, India. Indian Journal of Animal Research. DOI: 10.18805/IJAR.B-4754.

Submitted: 19-08-2021 Accepted: 08-12-2021 Online: 10-01-2022

Trichostrongylus spp. as the dominant parasites affecting small ruminants (Biu et al., 2012; Mohammed et al., 2016).

Generally, the policy of animal husbandry department of any state is to go for blanket deworming protocol to control the burden of parasitic infestation. However, it has been found that this trend has resulted in development of anthelmintic resistance (Chandrawathani, 2004; Domke et al., 2013).To overcome this problem, Dr. Faffa Malan evolved the technique for treating the animals infested with haemonchus by using clinical anaemia as the determinant. Subsequently, the name of the FAMACHA has been coined from the name of the Dr Faffa Malan (Bath et al., 1996; VanWyk et al., 1997). The test is based on the assessment of colour variation of the conjunctival mucous membrane of the animal. The 
standard chart colour varies from pink red (normal) to white (anaemic), for which scores are allotted as 5 (normal) to 1 (anaemic) (Malan et al., 2001). Several studies have been conducted worldwide for the use of FAMACHA as diagnostic tool to correlate the anaemic status of the animals with the gastrointestinal worm load (Vatta et al., 2001; Kaplan et al. 2004; Burke et al., 2007; Loria et al., 2009; Mohammed et al., 2016; Prasanth et al., 2020). In the present study, prevalence of gastrointestinal parasites in the semi-intensive management system of farmer's flock of South Andaman district was investigated. The egg per gram of faecal load was estimated and was correlated with FAMACHA score of the goat.

\section{MATERIALS AND METHODS}

Semi-intensive goat management and selection of animals

In Andaman and Nicobar Islands, goats are mainly reared under open range conditions (Semi-intensive management system) with provision of shelter during night. The majority of the goats are Andaman local goat, Teressa goat and admixture of Malabari crosses. Out of total livestock population of 154,733 , goat constitutes $42 \%(65,324)$ (Sunder et al., 2019). The study was conducted in farmer's flock of three villages under Ferragunj Tehsil of South

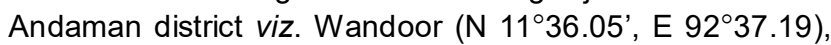

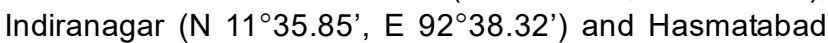
(N11'35.68', E 92 $\left.{ }^{\circ} 38.69^{\prime}\right)$. The study was conducted from August to December 2020. A total of 67 animals were selected for the present study. The history of the animals were recorded and found that goats and cattle are usually let for open grazing together in the same pasture land.

\section{Collection of faecal samples for egg count}

Faecal samples were collected from all the animals by per rectal method and collected in sterile container. The faecal samples were kept in ice box and taken to laboratory for examination of egg count. Modified method of McMaster technique was used for determination of egg per gram (EPG) using saturated salt solution as flotation fluid to quantify the number of eggs (Joshua et al., 2011, Rinaldia et al., 2011). On the basis of load of the parasitic eggs per gram of faecal content was categorised as mild infection (if count is less than 500), moderate infection (if count is ranges from 500 to 1500) and heavy infection (if count is more than 1500) (Chagas et al., 2008). The counting of the oocyst of coccidia was categorised as low (if the count is less than 1800), medium (if the count is between 1800 to 6000) and high (if the count is more than 6000) (Idris et al., 2012).

\section{Collections of blood samples for haematology}

Blood samples were collected from all the animals prior to deworming and 10 days post deworming. The blood $(1 \mathrm{ml})$ was collected from jugular vein and mixed in EDTA coated vials and kept at $4{ }^{\circ} \mathrm{C}$. Haemoglobin concentration was measured by Sahli's acid haematin method (Sonia et al.,
2012) and Haematocrit was estimated by micro-haematocrit method (Chowdhury et al., 2005). Total erythrocyte count (TEC) and total leucocyte count (TLC) were estimated by using Nambiar's diluting fluid (Bancroft and Marylin, 2008).

\section{Assessment of anaemia by using FAMACHA score card}

As per the standard procedure, FAMACHA was used to detect the colour of the conjunctival mucous membrane (Malan et al., 2001). The score was recorded as: 1 (red, non-anaemic), 2 (red pink, non-anaemic), 3 (pink, mild anaemic), 4 (pink white, anaemic) 5 (white, severely anaemic). Based on the scoring obtained, the animals were further segregated and treated with benzimidazole anthelmintic. After 10 days of the anthelmintic treatment all the animals were checked for FAMACHA score and faecal samples were examined for eggs per gram (EPG) and oocyst per gram (OPG) of faeces and blood were collected to check the haematology parameters.

\section{Statistical analysis}

Data were expressed as mean \pm S.E.M. Statistical reading and comparison among the group was performed by one way analysis of variance (ANOVA) by least significant differences (LSD) test with a $p$ value $\leq 0.05$ was considered significant (Snedecor and Cochran, 1994). One-way ANOVA was used to determine differences in all haematological indicators. Differences among groups were analysed for significance using Tukey's test.

\section{RESULTS AND DISCUSSION}

The prevalence of gastrointestinal parasites in the faecal sample was found to be $80.88 \%$, of which, the prevalence of Haemonchus spp., was very high (91.3\%) followed by Eimeria spp $(78.26 \%)$ and Strongyloides spp. (72.7\%) respectively. The EPG was found to be high for Haemonchus spp. (991.30 \pm 150.21$)$, medium to low for Strongyloides spp. $(469.56 \pm 77.37)$ and OPG was low for Eimeria spp. $(900 \pm 240.1)$ respectively. Based on the severity of the infection, it was found that the animals were moderately infected due to Haemonchus sp and low infection was recorded for Strongyloides spp. and Eimeria spp. The result of the load of EPG post deworming was found to be decreased significantly in Haemonchus $(525 \pm 75)$, Eimeria (195.65 \pm 55.33$)$ and Strongyloides $(78.26 \pm 33.83)$ (Fig 1).

A significant difference $(P<0.05)$ was detected in the haemoglobin content, ( $\mathrm{g} / \mathrm{dl})$ packed cell volume $(\%)$ and red blood cell (million $/ \mathrm{mm}^{3}$ ) of the animals before and after deworming treatment. However, there is no significant difference was observed for the white blood cell count (thousands/ $\mu$ l) (Table 1).

The result of the FAMACHA score of the animals prior to deworming treatment was $4.08 \pm 0.11$. The value was significantly improved to $3.2 \pm 0.13$ post deworming treatment. The correlation of the FAMACHA score with the haemoglobin content of the blood was significantly negatively correlated ( $r$ value $=-0.89)$. The level of the haemoglobin increased with decrease in the FAMACHA score (Table 2). 
In the present study, the prevalence of gastrointestinal parasites viz. Haemonchus spp., Strongyloides spp. and Eimeria spp. was found to be high. This could be due to the semi-intensive type of management system, wherein both cattle, goat and other livestock are allowed to graze together in the same pasture land (Gawor et al., 2006; Mohammed et al., 2016). The hot-humid and coastal climatic conditions of the islands further aggravates the proliferation of the gastrointestinal parasites (Sunder et al., 2019). However, the load of the egg/oocyst per gram of faecal content of the gastrointestinal parasites was low to medium. The findings of present study is in agreement with the occurrence of gastrointestinal parasites in India, Mynmar and other areas (Chikweto et al., 2018; Sivajothi and Reddy, 2018; Win et al., 2020;. The prevalence of Haemonchus spp. was found to be very high $(91.3 \%)$ followed by Eimeria spp. (78.26\%) and Strongyloides spp. (72.7\%) respectively. However, the severity of the infection in terms of eggs/oocyst per gram of faecal content was not in accordance with the frequency of the prevalence rate of gastrointestinal parasites. The load of Eimeria spp. was found to be low without any apparent clinical manifestation/symptoms. Similarly, the load of Strongylodies spp was also found to be low. However, the load of Haemonchus spp. was found to be moderately high. Haemonchus spp. is considered to be one of the most common GIN reported in small ruminants (Kaplan et al., 2004; Hassum, 2014; Sivajothi and Reddy, 2018). There are several reports available, in which the prevalence of GIN parasites varied from $50.51-86.05 \%$ from different parts of India (Pathak and Pal 2008; Tariq et al., 2010; Choubisa and Jaroli 2013; Gul and Tak, 2016; Dappawar et al., 2018; Verma et al. 2018) and similarly from other parts of the world
(Ntonifor et al., 2013), Slovakia (95.9\%) (Babjak et al., 2017), West Indies (98\%) (Chikweto et al., 2018) and Iraq (91.5\%) (Hassan and Barzinji 2018). The variation in occurrence of different percent prevalence of GIN parasites might be due to different agro-climatic situations prevailing in the different region and zones. Generally, the occurrence of most of the GIN parasites are subclinical in nature and rarely exhibit any clinical symptoms which is correlated with the age, health status, management condition and climatic condition. In the present study also, we have recorded the occurrence of medium to low level of GIN parasites infestation in goats without showing any clinical sign or symptoms. Generally, Haemonchus spp. are responsible for blood loss due to sucking of blood from the intestinal mucous of the animals which in turn responsible for anaemic status (Love and Hutchinson, 2003). In the present study also, prevalence of haemonchus was found to be high.

In the present study, the FAMACHA scores of the animals showed that very high percentage of animals $(54.05 \%)$ were in the category of score 4 , while $27.02 \%$ were in the category of score 5 . Only $18.91 \%$ of the animals were found to be non-anaemic and falls under the category of FAMACHA score 3. The blood parameters analysis revealed that the $\mathrm{Hb}$ level in the animals with FAMACHA score of 3 was $10.08 \pm 0.07$, score of 4 was $8.54 \pm 0.14$ and score of 5 was $6.78 \pm 0.16$ respectively. The result of the FAMACHA score is in line with the faecal egg count, wherein almost $90 \%$ of the animals were infested with GI parasites. Hassum et al. (2014) also reported low faecal egg count in the animals with FAMACHA score of 1 and 2 . Highly significant $(P<0.01)$ correlation was observed between the FAMACHA score and the haemoglobin level with $r$ value of 0.89 . This shows that

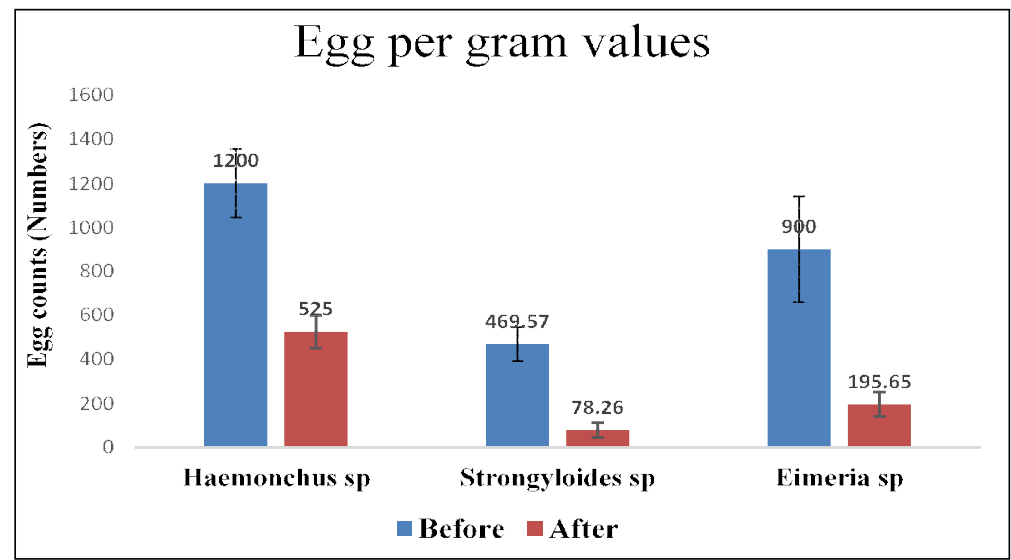

Fig 1: Prevalence of gastrointestinal parasitic infection (EPG) before and after deworming. ${ }^{* *} p \leq 0.01,{ }^{* \star *} p \leq 0.001$

Table 1: Haematology parameters before and after deworming.

\begin{tabular}{lcccc}
\hline Parameters & Before deworming (Mean \pm SE) & After deworming (Mean \pm SE) & P - Value & Result \\
\hline Haemoglobin (g/dl) & $8.32 \pm 0.22$ & $9.03 \pm 0.12$ & 0.0048 & $* *$ \\
PCV\% & $22.71 \pm 0.66$ & $24.95 \pm 0.70$ & 0.0237 & $*$ \\
RBC (millions/mm3) & $13.84 \pm 0.45$ & $14.99 \pm 0.33$ & 0.0400 & $*$ \\
WBC (NS) (Thousands/ $/ \mathrm{l})$ & $17937.0 \pm 1180.9$ & $19392.5 \pm 1069$ & 0.3631 & $\mathrm{NS}$ \\
\hline
\end{tabular}

**Highly significant $\mathrm{P} \leq 0.01$, *Significant $\mathrm{P} \leq 0.05$. 
Use of FAMACHA to Detect Anaemia and Control of Gastrointestinal Parasite in Goats of A and N Islands, India

Table 2: Correlation of FAMACHA with $\mathrm{Hb}$ level.

\begin{tabular}{lccc}
\hline Parameters & $\begin{array}{c}\text { Before } \\
\text { deworming }\end{array}$ & $\begin{array}{c}\text { After } \\
\text { deworming }\end{array}$ & r value \\
\hline FAMACHA Score & $4.08 \pm 0.11$ & $3.2 \pm 0.13$ & -0.8967 \\
Hb level & $8.45 \pm 0.20$ & $9.03 \pm 0.12$ & \\
\hline
\end{tabular}

the $\mathrm{Hb}$ level decreases, if the FAMACHA score increases which in turn reflects the anaemic status of the animals. The presence of high load of GIN parasites are responsible for poor health status of the animals and thereby decreases the $\mathrm{Hb}$ level. The average PCV level of the animals were found to be $22.71 \pm 0.66$, which is considered to be low. The $\mathrm{Hb}$ and PCV level are directly related with the health status of the animals. If the animals are infected with high parasitic load and there is loss of blood due to intestinal parasites, the value of $\mathrm{Hb}$ and PCV decrease. In the present study, there is highly significant correlation was found between FAMACHA score and the $\mathrm{Hb}$ content.

Kaplan et al., 2004 and Malan et al., 2001 showed positive correlation with the FAMACHA score and faecal egg count. In the present study, we also found decrease in the level of faecal egg count with FAMACHA score and $\mathrm{Hb}$ value. The high level of faecal egg count during this study period might be due to the high load of parasites in the pastures. Reports also suggested that parasitic cases are more observed during this period in this region (Sunder et al., 2019).

All the animals treated with benzimidazole anthelmintic showed significant response and reduction in the faecal egg count, improvement in the FAMACHA score, $\mathrm{Hb}$ level, PCV level and $\mathrm{RBC}$ count. The result of the post deworming egg count and blood parameters showed that FAMACHA is very important tool in the field to correlate the anaemic status of the animals with the GIN parasitic load. The use of this tool is very simple and can easily be transferred to the farmer's field as gold standard test for rapid detection and accurate treatment of the animals. In the present study $81 \%$ of the animals were found to be anaemic with FAMACHA score of 4 and 5 . All of these animals were treated with anthelmintic. The result of the post deworming showed significant reduction in faecal egg count and improvement in FAMACHA score. Several reports are available worldwide, wherein the use of FAMACHA has been successfully described in the small ruminants (Van Wyk et al., 1997; Chaudary et al., 2007; Burke et al., 2007; Mohammed et al., 2016; Mohammedsalih et al., 2019; Hassum et al., 2020). Vilela et al. (2008) also reported that despite of the moderately high load of faecal egg count (1300), the animals had no signs of illness. Burke et al., 2007 reported significant correlation between FAMACHA score and the faecal egg count.

Initially, the FAMACHA score card was developed with the idea to identify individual animals which requires anthelmintic treatment thereby to reduce the anthelmintic resistance problems. Later on this technique has been globally accepted and has been used in the flock to detect the health status of the animals and devising strategy for the anthelmintic treatment. The use of the FAMACHA has also been recommended for routine health check-up of the animals at regular interval (Mahieu et al., 2007; Riley and Van, 2009).In the recent years, the development of anthelmintic resistance due to the non-judicious practice of drenching has been evolved as the serious concern worldwide (Chanrawathani, 2004; Domke et al., 2013). Generally, it has been seen that in most of the cases, the animals are showing subclinical symptoms of the GI parasitic infestation. This might be due to the fact that the load of the parasites is below the threshold level or the parasites are developed fully/partial resistant to anthelmintic (Tan et al., 2014). In the present study also, similar type of observation were reported. Overall, health status of the animals were found to be below normal, with low FAMACHA score, low $\mathrm{Hb}$ level and other blood parameters. However, the animals did not exhibit any clinical symptoms. Similar type of observation were also reported by Abott et al., 1986 and Mavrot et al., 2015. Usually, the management and treatment of gastrointestinal parasites is by drenching heavy load of anthelmintic which has led to the development of anthelmintic resistance worldwide (Mortensen et al., 2003; Kaplan et al., 2004). Vanessa et al. (2014) showed that with effective use of FAMACHA for treatment of GIN parasites could reduce the cost of the medication by $75.6 \%$. Therefore the use of FAMACHA with effective and specific treatment of GIN parasites will certainly help in reducing the cost of unwarranted expenditure on the deworming and thereby help in reducing the burden of anthelmintic resistance.

The climatic condition of the place and region plays an important role in proliferation of the GIN parasites. The climate of $\mathrm{A}$ and $\mathrm{N}$ islands is hot and humid, thus the prevalence of parasitic infestation is very high (Sunder et al., 2019). Study with similar climatic conditions also reported the high prevalence of GIN parasites (Gadahi et al., 2009; Domke et al., 2013; Mohammed et al., 2016). In addition to the climatic condition the management of the animals also plays an important role in the prevalence of parasitic cases. In this island the animals are generally allowed for open grazing in the pasture with other livestock and there is high possibility of transmission of parasites through faecal material between the different livestock.

\section{CONCLUSION}

Based on the result of the present study, it could be concluded that FAMACHA is a very handy tool to detect anaemic status of the animals in the field. Thereby the cost of unnecessary anthelmintic could be avoided and the anthelmintic resistance could be prevented. The other advantage of the FAMACHA is that it can effectively be used for diagnostic purpose, if the same animal is being infected with frequent parasitic load. This could save money in unwarranted treatment and will be used to cull the animal if the same animal is being consistently infected. The study also established highly significant correlation between the FAMACHA score and $\mathrm{Hb}$ level. The present study successfully examined and detected the animal's suffering 
from anaemia due to GIN parasites and subsequent treatment with anthelmintic cured the animals from anaemia and GIN parasitic load. The FAMACHA tool is very handy and can easily be used by any layman or farmer. It is recommended that the FAMACHA score card should be propagated in the farmer's field for its effective use and correct diagnosis and treatment of the animals to avoid the risk of anthelmintic resistance.

\section{ACKNOWLEDGEMENT}

The authors are grateful to the farmers of the South Andaman villages for providing the dung samples from the animals as well as the ICAR-ADMAS and ICAR-AICRP Goat Improvement project for funding.

\section{REFERENCES}

Abott, K.A., Taylor, M., Stubbings, L.A. (1986). Sustainable worm control strategies for sheep, $3^{\text {rd }}$ ed., SCOPS Publishing.

Annual Report. (2018-19), ICAR-CIARI, Port Blair, pp. 327.

Babjak, M., Konigowa, A., Urda-Dolinska, M., Varady, M. (2017). Gastrointestinal helminth infections of dairy goats in Slovakia. Helminthology. 54: 211-217.

Bancroft, J.D., Marilyn, G. (2008). Theory and Practice of Histological Techniques. Sixth edition.

Bath, G.F., Malan F.S., Van Wyk J.A. (1996). The FAMACHA and Ovine Anaemia Guide to assist with the control of haemonchosis, In: Proceedings of the $7^{\text {th }}$ Annual Congress of the Livestock Health and Production Group of the South African Veterinary Association, Port Elizabeth. 5-7 June, p. 5.

Biu, A.A., Paul, B.T., Konto, M., Ya'uba, A.M. (2012). Cross sectional studies on oesophagostomosis in slaughter cattle In Maiduguri, Nigeria. CENRESIN Journal of Agriculture and Veterinary Sciences. 4: 22-27.

Burke, J.M., Kaplan, R.M., Miller, J.E., Terrill, T.H., Getz,W.R., Mobini, S., Valencia, E., Williams, M.J., Williamson, L.H., Vatta, A.F. (2007). Accuracy of the FAMACHA system for onfarm use by sheep and goat producers in the south eastern United States. Veterinary Parasitology. 147: 89-95.

Chagas, A.C.S., Vieira, L.S., Freitas, A.R., Araújo, M.R.A., AraújoFilho, J.A., Araguao, W. R., Navarro, A. M.C. (2008). Anthelmintic efficacy of neem (Azadirachtaindica A. Juss) and the homeopathic product FatorVermes ${ }^{\circledR}$ in Morada Nova sheep. Veterinary Parasitology. 151: 68-73.

Chandrawathani, P. (2004). Problems in the control of nematode parasites of small ruminants in Malaysia. In: Resistance to anthelmintics and the biological control alternative. Doctoral thesis. Swedish University of Agricultural Science.

Chaudary, F.R., Khan, M.F.U., Qayyum, M. (2007). Prevalence of Haemonchuscontortus in naturally infected small ruminants grazing in the Potohar area of Pakistan. Pakistan Veterinary Journal. 27: 73-79.

Chikweto, A., Tiwari, K., Bhaiyat, M.I., Carloni, J., Pashain, K., Pashain, A., Allie, C.D., Sharma, R.N. (2018). Gastrointestinal parasites in small ruminants from Grenada, West Indies: ancoprological survey and a review of necropsy cases. Veterinary Parasitology. 13: 130-134.
Choubisa, S.L., Jaroli, V.J. (2013). Gastrointestinal parasitic infection in diverse species of domestic ruminants inhabiting tribal rural areas of southern Rajasthan. Indian Journal of Parasitic Diseases. 37: 271-275.

Chowdhury, S.R., Smith, T.K., Boermans, H.J., Woodward, B. (2005). Effects of feed-borne fusarium mycotoxins on hematology and Immunology of Turkeys. Poultry Science. 84: 16981706.

Dappawar, M.,Khillare, B.,Narladkar, B.,Bhangale, G. (2018). Prevalence of gastrointestinal parasites in small ruminants in Udgir area of Marathwada. Journal of Entomology and Zoology Studies. 6: 672-676.

Domke, A.V.M., Chartierb, C., Gjerdec, B., Leined, N., Vatne, S., Stuen, S. (2013). Prevalence of gastrointestinal helminths, lungworms and liver fluke in sheep and goats in Norway. Veterinary Parasitology. 194: 40-48.

Gadahi, J.A., Arshed, M.J., Ali, Q., Javaid, S. B., Shah, S.I. (2009). Prevalence of gastrointestinal parasites of sheep and goat in and around Rawalpindi and Islamabad. Veterinary World. 2: 51-53.

Gawor, J., Kornas, S., Charcenko, V., Nowosad, B., Skalska, M. (2006). Intestinal parasites and health problems in horses in different breeding systems. Medycyna Weterynaryjna. 62: 331-334.

Gul, N. and Tak, H. (2016). Prevalence of Trichuris spp. in small ruminants slaughtered in Srinagar District ( $\mathrm{J}$ and $\mathrm{K}$ ). Journal of Parasitic Diseases. 40: 741-744.

Hassan, H.F., Barzinji, A.K.R. (2018). Prevalence of ruminants gastro-intestinal parasites in Kirkuk province, Iraq. Kirkuk University Journal-Scientific Studies. 13: 96-108.

Hassum, I.C. (2014). Famacha method as a tool for selective control of nematode parasites in sheep. Revista Brasileira de Medicina Veterinaria. 36: 251-254.

Idris, A., Moors, E., Sohnrey, B., Gauly, M. (2012). Gastrointestinal nematode infections in German sheep. Parasitology Research. 110: 453-1459.

Joshua, P.A., Sweenya, R.D., Ryana, U.M., Caroline, J., Woodgate, R.G. (2011). Comparison of molecular and McMaster microscopy techniques to confirm the presence of naturally acquired strongylid nematode infections in sheep. Molecular and Biochemical Parasitology. 180: 62-67.

Kaplan, R.M., Burke, J.M., Terril, T.H. (2004). Validation of the Famacha eye color chart for detecting clinical anemia in sheep and goats on farms in the southern United States. Veterinary Parasitology. 123: 105-120.

Loria, A.D., Veneziano, V., Piantedosi, D., Laura, R., Mezzino, L., Giuseppe, C., Ciaramella, P. (2009). Evaluation of the FAMACHA system for detecting the severity of anaemia in sheep from southern Italy. Veterinary Parasitology. 161: 53-59.

Love, S.C.J. and Hutchinson, G.W. (2003). Pathology and Diagnosis of Internal Parasites in Ruminants. In: Gross Pathology of Ruminants, Proceedings 350, Post Graduate Foundation in Veterinary Science, University of Sydney, Sydney, Chapter 16. 309-338.

Mahieu, M., Arquet, R., Kandassamy, T., Mandonnet, N., Hoste, H. (2007). Evaluation of targeted drenching using Famacha@ method in Creole goat: Reduction of anthelmintic use and effects on kid production and pasture contamination. Veterinary Parasitology. 146: 135-47. 
Malan, F.S., Van Wyk, J.A., Wessels, C.D. (2001). Clinical evaluation of anaemia in sheep: early trials. Onderstpoot Journal of Veterinary Research. 68: 165-174.

Mavrot, F., Hertzberg, H., Torgerson, P. (2015). Effect of gastrointestinal nematode infection on sheep performance: A systematic review and meta-analysis. Parasites and Vectors. 8: 1-11.

Mohammed, K., Abba, Y., Ramli, N.S.B., Marimuthu, M., Omar, M.A., Abdullah, F.F.J., Sadiq, M.A., Tijjani, A., Chung, E.L.T., Lila, M.A.M. (2016). The use of FAMACHA in estimation of gastrointestinal nematodes and total worm burden in Damara and Barbados Blackbelly cross sheep. Tropical Animal Health and Production. 48: 1013-1020.

Mohammedsalih, K.M., Khalafalla, A., Bashar, A., Abakar, A., Hessain, A., Juma, F.R., Coles, G., Krücken, J., Samson-Himmelstjerna, G.V. (2019). Epidemiology of strongyle nematode infections and first report of benzimidazole resistance in Haemonchus contortus in goats in South Darfur State, Sudan. BMC Veterinary Research. 15: 184-197.

Mortensen, L.L., Williamson, L.H., Terrill, T.H., Kircher, R., Larsen, M., Kaplan, R.M. (2003). Evaluation of prevalence and clinical implications of anthelmintic resistance in gastrointestinal nematodes of goats. Journal of Animal and Veterinary Medicine Advances. 23: 495-500.

Ntonifor, H., Shei, S., Ndaleh, N., Mbunkur, G. (2013). Epidemiological studies of gastrointestinal parasitic infections in ruminants in Jakiri, Bui Division, North West Region of Cameroon. Journal of Veterinary Medicine and Animal Health. 5: 344-352.

Pathak, A. and Pal, S. (2008). Seasonal prevalence of gastrointestinal parasites in goats from Durg district of Chhattisgarh. Veterinary World. 1: 136.

Prashanth, V., Kiran, H.J., Rupner, R.K.,Patil, S., Prakash, V.S. (2020). The "FAMACHA" Chart - An Alternate to Manage Haemonchosis in Small Ruminants - A Review Article. International Journal of Current Microbiology and Applied Sciences. 9: 1908-1913.

Riley, D.G. and Van, J.A. (2009). Genetic parameters for FAMACHA score and related traits for host resistance/resilience and production at differing severities of worm challenge in a Merino flock in South Africa. Veterinary Parasitology. 164: 44-52.

Rinaldia, L., Colesb, G.C., Maurellia, M.P., Musellac, V., Cringolia, G. (2011). Calibration and diagnostic accuracy of simple flotation, McMaster and FLOTAC for parasite egg counts in sheep. Veterinary Parasitology. 177: 345-352.

Sani, R.A. and Chandrawathani, P. (1996). Gastrointestinal parasitism in small ruminants in Malaysia. In: ACIAR Proceedings. pp. 98-100.

Sivajothi, S. and Reddy, B. (2018). Seasonal prevalence of gastrointestinal parasites of small ruminants in YSR Kadapa district of Andhra Pradesh, India. International Journal of Livestock Research. 8: 184-189.

Snedecor, G.W. and Cochran, W.G. (1994). Statistical Methods, $8^{\text {th }}$ edn, Oxford and IBH Publishing Company, New Delhi, India.
Sonia, C., Rajini, R.A., Babu, M.,Vairamuthu, S. (2012). The effect of age, sex and rearing system on differential count in Guinea fowl. Indian Journal of Poultry Science. 47: 251253.

Sunder, J., Sujatha, T., De, A.K., Bhattacharya, D., Ponraj, P., Kumar, L., Kundu, A. (2019). Temporal and Spatial Epidemiological Trend of Emerging Livestock Diseases of Andaman and Nicobar Islands, India. International Journal of Applied Research in Veterinary Medicine.17: 29-40.

Tan, T.K., Panchadcharam, C., Low, V.L., Lee, S.C.,Ngui, R., Sharma, R.S., Lim, Y.A. (2014). Co-infection of Haemonchuscontortus and Trichostrongylus spp. among livestock in Malaysia as revealed by amplification and sequencing of the internal transcribed spacer II DNA region. BMC Veterinary Research. 10: 1.

Tariq, K.A., Chishti, M.Z., Ahmad, F. (2010). Gastro- intestinal nematode infections in goats relative to season, host, sex and age from the Kashmir valley. Indian Journal of Helminthology. 84: 93-97.

Van Wyk, J.A., Malan, F.S., Bath, G.F. (1997). Rampant anthelmintic resistance in sheep in South Africa what are the options? In: [Van Wyk J.A., Van Schalkwyk P.C.,] Managing Anthelmintic Resistance in Endoparasites. Workshop held at the 16th International Conference of the World Association for the Advancement of Veterinary Parasitology. 10-15 August, Sun City, South Africa, pp. 51-63.

Van Wyk, J.A., Bath, G.F. (2002). The FAMACHA system for managing haemonchosis in sheep and goats by clinically identifying individual animals for treatment. Veterinary Research. 33: 509-529.

Vanessa, D.V., Feitosa, T.F., Vilela, V.L.R., Azevedo, S.S., Net, J.L.D.A., Dayana F.D.M., Ana, R.C.R.,Athayde, A.C.R. (2014). Prevalence and risk factors associated with goat gastrointestinal helminthosis in the Sertao region of Paraiba State, Brazil. Tropical Animal Health and. 46: 355-361.

Vatta, A.F., Letty, B.A., Linde, M.J., Wijk, E.F., Hansen, J.W., Krecek, R.C. (2001). Testing for clinical anaemia caused by Haemonchus spp. in goats farmed under resource-poor conditions in South Africa using an eye colour chart developed for sheep. Veterinary Parasitology. 99: 1-14.

Verma, R., Sharma, D.K., Paul, S., Gururaj, K., Dige, M., Saxena, V.K., Rout, P.K., Bhusan, S., Banerjee, P.S. (2018). Epidemiology of Common Gastrointestinal Parasitic Infections in Goats reared in Semi-Arid Region of India. Journal of Animal Research. 8: 39-45.

Vilela, V.L.R., Feitosa, T.F., Linhares, E.F., Athayde, A.C.R., Molento, M.B., Azevedo, S.S. (2008). FAMACHA@ method as an auxiliary strategy in the control of gastrointestinal helminthiasis of dairy goats under semiarid conditions of Northeastern Brazil. Veterinary Parasitology. 190: 281-284.

Win, S.Y., Win, M.,Thwin, E.P., Htun, L.L., Hmoon, M.M., Chel, H.M., Thaw, Y.N., Soe, N.C., Phyo, T.T., Thein, S.S., Khaing, Y., Than, A.A., Bawm, S. (2020). Occurrence of Gastrointestinal Parasites in Small Ruminants in the Central Part of Myanmar. Journal of Parasitology Research. doi.org/10.1155/2020/8826327. 